\title{
GÁLNÉ HORVÁTH ILDIKÓ:" A tanyai lakosság szerepe és helye a vidéki élet vérkeringésében
}

\section{Summary}

The Great Hungarian Plain one of the - nowadays mentioned as a 'Hungaricum' in the literature - form of settlement; the population living on the farms occupies specific place in the Hungarian society.

Before years - centuries - of collectivization of the agriculture inhabitants working in agriculture, earning money from it was understand in the literature.

Nowadays all this an occupational construction, all of them all changed a lot in the look of commerce.

The peasantry had its share of a determining role in the Hungarian society's establishment in the course of the centuries; let it be an economy, sociology, a tradition, etc. In the past twenty years did not let the farms untouched. New inhabitants, who reveal a quite heterogeneous picture to us considering their occupation, their conduct, their social role, appeared on the farms.

\section{Bevezetés}

Hazánk lakosságának 2\%-a él tanyán, mely az Alföld lakosságának 6-8\%-át teszi ki. Ez azt jelenti, hogy az alföldi tanyák körülbelül 200000 embernek adnak otthont, megélhetési lehetöséget, sokaknak kikapcsolódást, egyeseknek a szabadság érzését (Uhlig R., 2008).

A tanyák társadalmi-gazdasági megítélése már létezésük kezdetétől fogva korántsem volt egyértelmü. Számos érv szólt mellettük, és egyes vélemények szerint ugyanannyi szólt ellenük. Az elmúlt 150 évben a vélemények folyamatosan megoszlanak, közben tanyák tünnek el és keletkeznek újak az Alföldön.

A létjogosultság kérdését félre téve tény, hogy az itt élö lakosság tevékenységével szerves részét alkotja a magyar lakosságnak, a zárt települések lakóihoz hasonlóan egyaránt részt vállalnak az ország mindennapi életében mind gazdasági, mind társadalmi tényezőket tekintve.

Mindenesetre fontos szem elött tartani azt a kérdést, mely szerint indokolt-e támogatni a tanyák fennmaradását, mint sajátos település- és gazdasági egységet, vagy sorsukra hagyni őket a globalizációs folyamatok sodrásában?

\section{A tanya és a tanyai életforma múltja és jelene}

Az alföldi tanyák kialakulását tekintve le kell szögezni, legkiterjedtebb tanyarendszerrel, a nagy külterülettel rendelkező városok rendelkeztek. A török hódoltságot követően az újraéledő települések határában jöttek létre ezek az időszakosan lakott szállások, ahol kezdetben az állatokat tartották, majd később ún. kertek jöttek létre, ahol növénytermesztést folytattak. Az itteni életforma kettős kötődést jelentett. Az otthon a munkából kiöregedett nagyszülők és az iskolába járó gyerekek mezővárosi lakását jelentette, míg ,a tanyán kikelettől természetnyugvásig a paraszt gazdálkodó” (Szenti T., 2001) családtagok éltek, akik télire a mezőgazdasági munkák szünetében a városi házba költöztek.

\footnotetext{
*PhD hallgató - PTE Földtudományok Doktori Iskola, NLG Hódmezővásárhely.
} 
Az alföldi tanyarendszer a 19. század utolsó harmadában „tanyavilággá" (SZENTI T. 2001.) fejlődött. A földterületek elaprózódásával, amely az örökösök közti felosztás következménye, lazult a kapcsolat a várossal, már nem minden tanyai családnak volt háza a városban. A 19-20. század fordulóján a mezỏvárosok tanyavilágában élt a lakosság harmadrésze (Szenti T., 2001). Lakó- és munkahely egységet képezett, ahol a parasztcsaládok növényt termesztettek, állatot tartottak, a felesleges termést, jószágot pedig értékesítették.

A város és tanyavilága között sajátos kapcsolat alakult ki: A mezỏvárosokban kialakult céhes ipar termékei és a tanyákon megtermelt javak cseréltek gazdát a heti piacokon és az éves kirakódó vásárokon. A valóság azonban távolról sem volt soha ilyen ideális. A várostól távolabb lakók hivatalos ügyeik intézése, gyermekeik iskoláztatása (elemi képzés), a dülöutak járhatósága; mind jogos igényként merült fel, melyet a városok vezetői nem oldották meg, noha a tanyai lakosság is kivette részét a közteherviselésből. Érthető, hogy ez feszültséget jelentett a város és tanyai lakosság között.

„Akar jobb úton közlekedni, akar postát kapni legalább hetenként kétszer, akarja, hogy az orvos időnként kint rendelőórát tartson... Ezek igazán nem valami forradalmi kívánságok, hanem jogos igények kielégítésére való törekvések azokért az anyagi szolgáltatásokért, amelyeket a tanyai magyar évtizedeken át becsülettel kiizzad a belterület érdekében." (Gesztelyi Nagy L., 1932).

Az ezt követö évtizedekben a külterületi lakosság sorsa nem vált könnyebbé, dacára annak, hogy iskolák épültek a tanyavilágban. Számos kérdés azonban nem oldódott meg, így az orvosi, állatorvosi ellátás, amely a községben, városban volt, a dülöutak karbantartása, sok helyuitt kiépítése is elmaradt.

A második világháború utáni földosztás által számos nincstelen parasztcsalád is földhöz juthatott, a rég áhított kisbirtokok reménybeli megélhetést biztositottak, a régi tanyaépületeket felújították, az üres telkeken új házakat építettek.

A kollektivizálás az '50-es években azonban romba döntötte a tanyavilág fejlödését. Új épületek építését megtiltották, a régieket csak javítani lehetett (Szenti T., 2004).

Összefoglalva „megszünt a tanyák létének korábban ismert társadalmi-gazdasági alapja, s így megindult a tanyavilág pusztulási folyamata" (Becsei J., 2002).

A folyamat azóta tart, a tanyai lakosság nagy része a közeli településekre költözött, felhagyott a korábbi paraszti élettel, gyárakban helyezkedett el. Az idősebbek segédmunkásként, betanított munkásként, a fiatalabbak és a gyerekek szakmát tanultak, a kiemelkedően jó képességüek egyetemet, főiskolát végeztek. Az alföldi tanyai lakosság körében jól követhetỏen zajlott le a foglalkozási átrétegzỏdés.

A kényelmesebb városi életmód, a magasabb szintủ infrastrukturális ellátottság olyanynyira elösegítette a külterületi népesség fogyását, hogy egyes társadalomtudósok a magyar tanyarendszer végleges megszủnését jósolták (Hornyák S., 2009).

A rendszerváltás éveiben sokan a tanyák reneszánszára számítottak. A szövetkezeti rendszer felbomlásával sokan költöztek ki a tanyákra. A régi, leromlott épületeket igyekeztek lakhatóvá tenni, a tehetősebbek új házakat építettek.

A tanyák sorsa azonban nem változott. A külterületi lakosság összetétele is meglehetősen heterogén, gazdasági, anyagi helyzete szintén. Hiányzik a kellỏ szakértelem, megfelelő tőke, gyakori probléma egyes rétegek érdektelensége is.

Megszủnt a tanyákon a közbiztonság, gyakoriak a betörések, a terméslopás, a tiltott termékek előállítása.

Az alföldi épített táj sajátossága a romos, üres, elhagyott tanyák és modern kastélyszerũ épületek váltakozása.

Mindezek ellenére a népesség migrációjának változása figyelhetỏ meg. Míg korábban a tanyákról, falvakból a városba vándoroltak, addig napjainkban ez a vándorlás megfordulni látszik. 


\section{A tanyai lakosság összetétele, helyzete, szerepe}

A tanyai lakosság összetételének vizsgálatakor több tényezőt kell megemlítenünk. Egyrészt fontos a korösszetétel. 100-150 évvel ezelött, a tanyák létrejöttének kezdetén, az aktív korúak éltek a tanyákon, az idősek és a gyerekek pedig a városban.

Az 1950-es évektől kezdődően azok az aktív munkavállaló korban lévők maradtak tanyájukon, akik valamilyen módon kapcsolatban maradtak a földdel: vagy a helyi termelöszövetkezetben, állami gazdaságban dolgoztak, vagy a városban, de házuk a hozzá tartozó háztáji földdel megmaradt. Esetükben a nagyüzemi mezőgazdasági nagyüzemek létrehozásával sem szüntették meg teljesen háztáji, munkaigényes gazdaságukat. Gyakran ezek a családok rendelkeztek a városban, közeli faluban, vagy községben házzal, ahol idős szüleik, vagy iskoláskorú gyermekeik laktak. Ez azoknál a családoknál volt jellemző, ahol nem volt a tanyavilágban iskola.

A '80-as években a korábbi lakosság elöregedett, elhalt, tanyáikat értékesítették. Ezekbe az épületeket föleg pihenés vagy gazdálkodás céljára vásárolták meg városban - általában lakótelepen élö - családok. E tanyák nagy része ideiglenesen volt lakott, hétvégeken, szabadságok idején. A gazdálkodásra használt tanyákon az állatok etetése miatt naponta megjelent a gazda, de ezeknek a hajlékoknak sem volt állandó lakója.

A rendszerváltás utáni években megszaporodott a tanyai lakosság. Napjaink tanya lakóinak egy része kárpótlás során visszakapott földjeik birtokbavétele miatt költözött ki. A kellö tőkével, szakértelemmel rendelkezők jól müködő gazdaságokat, farmokat, lovas- és üdülötanyákat hoztak létre. Reális esélye a fennmaradásra e tanyatípusoknak van (Csatári et. al, 2005).

A kisebb tőkével rendelkezők a mezőgazdasági termékek eladásával járó országos agárgondok ellehetetlenítik a termelést, a tanyák létét. Nincs lehetőség tőke hiányban a géppark fejlesztésére, a gazdák megfelelö érdekképviseletének hiánya tanyájuk, itteni életük létét veszélyezteti.

Mások az olcsóbb megélhetés (kisebb rezsi költség, konyhakertbe megtermelhetỏ élelmiszer stb.) reményében vásároltak még lakható, de felújításra szoruló tanyákat. Ezek egy részét felújították, még ma is lakják őket, annak reményében, ha elegendő megtakarított pénzük gyülik össze, visszaköltöznek a városba. Másokat miután életveszélyessé vált az épület, újdonsült lakói sorsukra hagyták, visszaköltözve a városba, albérletekbe, szüikséglakásokba. Ebbe a csoportba gyakran a társadalom perifériáján, nehéz megélhetési körülmények közt élö családok tartoznak (Szenti T., 2004).

A tanyai lakosság legnehezebb helyzetben lévő csoportját azok az idős emberek alkotják, akik az elmúlt 40 év során tanyájukon élték végig a tanyatörténelem viharait. Önhibájukon kívül jövedelmük alacsony, hajlékuk értéktelen, felújításra, gyakran bontásra vár, alacsony jövedelmük miatt nem engedhetik meg maguknak, hogy a közeli településre költözzenek. Helyzetüket nehezíti, hogy közvetlen környezetük infrastrukturális ellátottsági foka alacsony, gyakran az alapellátás (villany, út stb.) is hiányzik. Lehetőségeik korlátozottak, mivel otthonaikhoz ragaszkodnak, helyzetükön nem lehet változtatni. Mindez sérti mindennapi életük érdekeit, mert környezetük nem mindig és nem mindenben biztosítja annak az életformának a megélését, amely társadalmi helyzetükböl következne, amit megérdemelnének. Esetükben fontos szerepe lenne a szociális gondoskodásnak, támogatásnak.

A tanyai lakosság társadalomban betöltött szerepe vitathatatlan. Mezőgazdasági termékeivel, adójával, pótadójával (Gesztelyi Nagy L., 1932), hagyományaival, szakértelmével fontos szerepe volt a vidéki élet vérkeringésében. A mezỏgazdaság kollektivizálása során, munkaerején és földjén felül személyes vagyontárgyaival (gépek, igavonó állatok), állatállományával indult meg a termelőszövetkezetek, állami gazdaságok müködése. 
A '60-as évek elejétỏl gyermekei számára az iskola lett a társadalmi mobilitás közvetítésének legfontosabb csatornája. Szerepét két tényezỏ növelte meg, egyrészt az iparosodással járó mủszaki, technológiai fejlődés, másrészt a földmagántulajdon megszüntetése, amellyel az öröklési tényező kiesett. A munkaerõ utánpótlást az iskolából kilépõ fiatalok jelentették. A végzettek döntỏ többsége a szakmunkásképzőből és szakközépiskolából kerültek ki. Ezek a fiatalok már nem költöztek vissza a szülői házba, a tanyára. A városban maradtak, ott alapítottak családot, szüleiknek ugyan segítettek az idénymunkák során, de gyermekeik már eltávolodtak ettől az életformától, egyben életszemlélettől is.

\section{Összefoglalás, jövőkép}

A tanyák a köztudatban rokonszenves, inkább romantikus mégis pusztulásra ítélt életformaként élnek a köztudatban. A rendszerváltást követően felcsillant ugyan a remény, høgy visszanyerik korábbi, napjainkra már-már utópisztikusnak mondható funkciójukat. Köztudott, ennek lehetõsége képtelenség elsösorban a megfelelő infrastruktúra és a szolgáltatások hiánya miatt. Amennyiben e két tényező fejlesztésére nem keruil sor, a tanyák fennmaradása kétséges lehet. Velük együtt fennáll a veszélye annak, hogy a jellegzetes alföldi kultúrtáj is eltünik.

Míg Európa nyugati részein zajlik a lakosság városokból vidékre áramlása, addig nálunk gyakran a már meglévő értékek, gazdaságilag, idegenforgalmilag jól funkcionáló tanyák alapellátása sem biztosított.

A problémák megoldása összetett feladat, melyek megoldására a politikusok, településkutatók, tanyakollégium is összefoglalták a legfontosabb feladatokat. Így az infrastruktúra, alapszolgáltatások fejlesztése mellett megoldásra vár még a tanyák közbiztonságának javítása, az Alföld néhány részén nem megoldott a külterületi lakosság valós érdekképviselete. Mindenképp szükséges megteremteni a fenntarthatóság feltételeit, mindezt a tanyás térségek eltérő természeti-gazdasági adottságok figyelembevételével.

\section{Irodalom}

Uhlig Rita (2008): Magyar Tanya. VKSZI Magyar Tanyákért Programiroda hírlevele. 2008. 01. 15. Szenti T. (2001): Tanyarendszerünk múltja és egyik jövőképe. Hitel. 8. pp. 68-79.

Gesztelyi Nagy L. (1932): A tanyavilág és népe. Nyugat. 21. szám.

Szenti T. (2004): A tanyalakók lelki egészsége. Hitel. 6. pp. 47-63.

Becsei J. (2002): A tanyarendszer jövőbeni alakulására ható tényezők, Magyar Tudomány. 9.

Bartha Szabó József (2009): Nemzeti feladat - lenne - a tanyák és tanyás térségek megőrzése, fejlesztése! Gondola.hu http://www.gondola.hu/cikkek/65265. 2009. 07. 29.

Hornyák S. (2009): Tanyák félúton. Új Magyarország Vidékfejlesztési Program. Vidékjáró http://www.umvp.eu/?q=magazin/tanyak-feluton. 2009.07. 29.

Csatári B. et al. (2005): (szerk. Kanalas I..): A homokhátsági tanyák jelene és progresszivitásuk kérdései, MTA RKK Alföldi Tudományos Intézete Tanyakutatás 2005. Kutatási jelentések, 5. füzet, Kecskemét.

sz.n.: Tanyakollégium 2002-2003 Zárónyilatkozata és ajánlásai. http://www.alfoldinfo.hw/ tanyakollegium/zaronyilatkozat.html. 2009. 06. 15. 